\title{
Correspondence
}

ChINA \& WTO ReV. 2017:2; 389-400

http://dx.doi.org/10.14330/cwr.2017.3.2.08

pISSN 2383-8221 • elSSN 2384-4388

China and WTO Review

\section{US-China Relations in Trump's First Term}

\author{
John Riley*
}

During the run up to the 2016 US presidential election, US presidential candidate Donald Trump eviscerated China on the campaign trail, blaming and characterizing it as the prime scapegoat for many of America's economic woes. Trump told a crowd in Indiana that the US "can't continue to allow China to rape our country" with respect to unfair trade practices and currency valuation. ${ }^{1}$ Trump and his advisors repeatedly threatened to label China a currency manipulator on day one in office and assess a 45 percent tariff on Chinese imports to punish Beijing for unfair trade practices. ${ }^{2}$ Once it became clear that Trump's campaign rhetoric could be effectuated following his victory in the presidential election, China publicly rejected the currency manipulation claims and avowed to protect its rights under the WTO and take a "tit-for-tat" approach with the US goods sold in China. ${ }^{3}$

In December 2016, Trump appointed Peter Navarro, a harsh China critic, to lead a White House effort to reshape American trade and industrial priorities. ${ }^{4}$ Mr. Navarro is a professor of economics at the University of California who has published extensively on the US-China trade relations. He has argued that China is waging economic war on the US by subsidizing its exports and impeding imports from the US. ${ }^{5}$ Consequently, the Trump campaign introduced a 7-point plan to reshape the US trade policy, three of which specifically targeted China by: (1) instructing the US Treasury Secretary to label China a currency manipulator; (2) instructing the US Trade Representative to bring trade cases against China

* Assistant Professor of Law at Sogang University School of Law; Attorney-at-Law (Pennsylvania Bar). J.D. (Pittsburgh). ORCID: http://orcid.org/0000-0002-7512-9090. The author may be contacted at: johnrileyoo7@gmail.com / Address: Sogang University School of Law, 35 Baekbeomro (Sinsu-dong), Mapo-gu, Seoul 04107 Korea. 
in the US and the WTO; and (3) using all available executive powers to remedy trade disputes between the US and China, including the application of tariffs in accordance with existing statutes. ${ }^{6}$

Following the election, Trump has become the first US President-elect to take a public call from the leader of Taiwan since Washington normalized relations with Beijing in 1979, resulting in an official complaint from the Chinese government. ${ }^{7}$ Shortly thereafter, Trump suggested in an interview with THE WALL Street Journal that he was open to ending the US' long-standing "One-China policy." ${ }^{8}$ This suggestion (which was later retracted) ${ }^{9}$ led to sharp criticism from Chinese Foreign Ministry spokesman, Shuang Geng who stated that if the "OneChina policy" was disrupted then the Sino-US bilateral cooperation would be "out of the question." ${ }^{10}$ An editorial in the Chinese state-run GLOBAL Times went even farther, claiming that Trump was "ignorant as a child in terms of foreign policy" and warned that a change in the "One-China policy" would spark "a real crisis." "11

In January 2017, President Trump delivered on one of his major campaign promises by withdrawing the US from the Trans-Pacific Partnership ("TPP"), the prior administration's signature trade deal. ${ }^{12}$ Trump indicated that his administration's trade policy would be conducted on a bilateral basis "to promote American industry, protect American workers, and raise American wages." By withdrawing from the TPP, Trump essentially declared an end to the era of multilateral trade agreements that has defined global trade for decades. However, it was heavily criticized by politicians in Washington, including many within his own party for abandoning long-standing Republican orthodoxy. ${ }^{14}$ Not a few commentators speculated that withdrawal from the TPP would open the door for China to gain economic influence in the South China Sea and gain the upper hand in a key trading region.

Considering Trump's lack of political experience, his strong use of anti-China rhetoric during the campaign and thereafter, his appointments of key White House staff who have been harshly critical of Chinese economic policy, and his actions since being sworn in as President, most notably the US withdrawal from the TPP, many prominent scholars have questioned whether the principles that have provided for continuity in the US-China relations since the 1970s will continue to guide the globe's key bilateral relationship on a stable path or push the two powers towards conflict. Robert Daly maintained: 
Both nations will be led, for the first time since the opening in 1979, by men who view the relationship in fundamentally adversarial terms (this is overt in Trump's case, implicit in Xi's). Their distrust reflects real strategic, economic, and ideological incompatibilities as well as the attitudes of their citizens; since 2014, a majority of Chinese and Americans have had a negative view of the other country. In China, there is a widespread belief that the U.S. is in irreversible decline and seeks to contain China, while a growing number of Americans, particularly in the foreign policy community, are convinced that China intends to replace the United States as the primary strategic actor, or hegemon, of Asia.

The U.S. and China are trying to navigate an inevitable competition amidst deep mutual suspicion and domestic fragility. This unpalatable brew could be rendered toxic by the addition of nationalism on either side or by the flaring of tensions in the Korean Peninsula, the Baltics, or the Middle East. Foreign affairs bureaucracies in Washington and Beijing cannot function normally under these circumstances. Roadmaps devised by both sides to encourage cooperation and defuse tensions are of limited use. As a result, the threat of wild card events pushing the United States and China toward conflict is greater than it has been at any time in nearly 40 years. ${ }^{16}$

Furthermore, congressional leaders from both parties have increased their antiChinese rhetoric over the last decade, calling for much stricter scrutiny in the US-China economic and trade policy. Many congressional leaders have called for increased review of Chinese foreign direct investment in the US following a series of large Chinese acquisitions of prominent American corporations in the telecommunications and food production industries. Following the merger of a Chinese corporation and Smithfields, e.g., the largest pork producer in the world, Senator Debbie Stabenow (Michigan) announced she was drafting legislation to require the government to assess economic and cultural ramifications of proposed foreign investment in the US. ${ }^{17}$ Likewise, other members of Congress have proposed carrying out an economic effects analysis for foreign investment in all sectors of the economy, not just those affecting national security. ${ }^{18}$ Thus, President Trump seems to be taking a position vis-à-vis China that has significant support across the political spectrum in the US.

However, the tension between the US and China began to ease noticeably beginning with the Mar-a-Lago summit when Trump attempted to win over Xi Jin-Ping to his "maximum pressure and engagement" approach to halting North 
Korea's nuclear weapons and ballistic missile development. ${ }^{19}$ Since the summit, Trump's China rhetoric has become significantly warmer, particularly as it relates to Xi. Most of Trump's public remarks concerning China have been tied directly to the North Korea's missile and nuclear issues, speaking highly of President Xi while at the same time attempting to persuade China to apply as much pressure as possible to the North Korean regime. The evolution of this rhetoric can be seen in the following Tweets in which Trump has mentioned China or President Xi since being sworn in. ${ }^{20}$

Table 1: Pre-Summit Tweets:

\begin{tabular}{l|l}
\hline March 17 & $\begin{array}{l}\text { North Korea is behaving very badly. They have been "playing" the } \\
\text { United States for years. China has done little to help! }\end{array}$ \\
\hline March 30 & $\begin{array}{l}\text { The meeting next week with China will be a very difficult one in } \\
\text { that we can no longer have massive trade deficits... }\end{array}$ \\
\hline
\end{tabular}

Table 2: Post-Summit Tweets:

\begin{tabular}{c|l}
\hline April 8 & $\begin{array}{l}\text { It was a great honor to have President Xi Jinping and Madame Peng } \\
\text { Liyuan of China as our guests in the United States. Tremendous... }\end{array}$ \\
\hline April 11 & $\begin{array}{l}\text { I explained to the President of China that a trade deal with the U.S. } \\
\text { will be far better for them if they solve the North Korean problem! }\end{array}$ \\
\hline April 11 & $\begin{array}{l}\text { North Korea is looking for trouble. If China decides to help, that } \\
\text { would be great. If not, we will solve the problem without them! } \\
\text { U.S.A. }\end{array}$ \\
\hline April 12 & $\begin{array}{l}\text { Had a very good call last night with the President of China concerning } \\
\text { the menace of North Korea. }\end{array}$ \\
\hline April 13 & $\begin{array}{l}\text { I have great confidence that China will properly deal with North } \\
\text { Korea. If they are unable to do so, the U.S., with its allies, will! } \\
\text { U.S.A. }\end{array}$ \\
\hline April 16 & $\begin{array}{l}\text { Why would I call China a currency manipulator when they are } \\
\text { working with us on the North Korean problem? We will see what } \\
\text { happens! }\end{array}$ \\
\hline
\end{tabular}




\begin{tabular}{c|l}
\hline April 21 & $\begin{array}{l}\text { China is very much the economic lifeline to North Korea so, while } \\
\text { nothing is easy, if they want to solve the North Korean problem, } \\
\text { they will }\end{array}$ \\
\hline April 28 & $\begin{array}{l}\text { North Korea disrespected the wishes of China \& its highly respected } \\
\text { President when it launched, though unsuccessfully, a missile today. }\end{array}$ \\
\hline May 12 & $\begin{array}{l}\text { China just agreed that the U.S. will be allowed to sell beef, and } \\
\text { other major products, into China once again. This is REAL news! }\end{array}$ \\
\hline
\end{tabular}

Trump's praise for President Xi and encouragement of China has also been reflected in official administration statements posted on the official website of the While House (whitehouse.gov), which the Chinese government takes seriously in determining their official policy. ${ }^{21}$ On April 17, e.g., Press Secretary, Sean Spicer stated as follows:

I think you see China playing a much more active role with respect to North Korea both politically and economically, that they can continue to apply pressure to achieve results. And I think we're going to continue to urge China to exhibit its influence in the region to get better results ...

The era of strategic patience was a policy that the Obama administration enacted to basically wait and see. I think we have now understood that that policy is not one that is prudent for the United States. And I think that's why you've seen stepped-up efforts, particularly with respect to China, and that's why I think the relationship that the President really is building on from the time that he spent down in Mar-a-Lago with President Xi is hopefully going to produce results . . .

What we're doing is working with the world community. And as I mentioned multiple times today, especially China, which is really acting in an historic way to ensure that our national interests and the safety of the Peninsula is protected. ${ }^{22}$

So what, if anything, can the first five months of the Trump administration tell us about the future of US-China relations? It is clear that the North Korea issue has taken precedent over the other US-China issues preceding the election, including currency valuation, trade and military disputes. The administration has publicly prioritized the halting North Korea's intercontinental ballistic missile ("ICMB") 
and nuclear weapons programs by pushing for the implementation of sanctions and secondary sanctions targeting private businesses transacting business with Pyongyang. ${ }^{23}$ Although China has backed the UN sanctions against North Korea in the past, it has not been actively enforcing such sanctions and in some cases has increased trade with Pyongyang. ${ }^{24}$ Currently, the administration appears to be willing to take a wait-and-see approach in order to determine China's willingness to actually enforce existing sanctions. The Secretary of State Rex Tillerson recently stated:

I'd say we're at about dial setting 5 or 6 right now, with a strong call of countries all over the world to fully implement the U.N. Security Council resolutions regarding sanctions, because no one has ever fully implemented those," he said. Tillerson warned other nations that the U.S. is closely watching how they carry out sanctions. $^{25}$

Secretary Tillerson has addressed that the US will employ secondary sanctions to target foreign companies (particularly banks) with or without international cooperation to ensure the North Korean regime feels significant financial pressure. He said:

\footnotetext{
We told them we're watching what you're doing, when we see you not implementing, we see companies, we see individuals that are violating these sanctions, we're going to contact you, we're going to ask you to take care of it ... If you can't take care of it, or you simply don't want to take care of it for your own internal political reasons, we will. We'll sanction them through third-country sanctions. ${ }^{26}$
}

These kinds of secondary sanctions, particularly in the financial sector, were very effectively employed by the Obama administration in bringing Iran to the negotiating table over its nuclear weapons program. David Cohen, former deputy director of the CIA and undersecretary of the Treasury for terrorism and financial intelligence during the Obama administration maintained:

When I was serving in the Treasury Department during the Obama administration, we employed secondary sanctions to significantly ramp up pressure on the Iranian government. Hundreds of foreign banks that had been transacting with sanctioned Iranian banks voluntarily severed those relationships, thereby isolating much of the Iranian banking system. 
Mr. Cohen and others believe that secondary sanctions against Chinese banks that aid North Korean front companies operating in China would be an effective way to tighten the financial noose around Kim Jong Un and drive a wedge between him and the Pyongyang elite that are critical to his power. ${ }^{27}$ Further, if past is prologue, such sanctions would likely not sour Washington-Beijing relations as they did not when the US sanctioned Chinese banks doing business with the Iranian regime. Much like the Iran situation, China knows that the US has intended to close financial loopholes available to the Kim Jong Un regime for years. Actually, the sanctions are the preferred alternative to military conflict and designed to spur a negotiated settlement over the ballistic missile and nuclear weapons programs. ${ }^{28}$ In fact, China's willingness to endure sanctions in Iran in order to avoid military strikes by the US would be even greater in order to avoid a potential US-led war on the Korean Peninsula. Scott Snyder said:

Despite China's uneasiness with a nuclear North Korea, however, China continues to see ramped up U.S. military pressure on North Korea as an even bigger concern.

An editorial in the state-run Global Times shows Beijing's frustration with a possible U.S. military response to Pyongyang's threats. And in a call between Trump and Xi on April 24, the Chinese president switched back to urging Trump to exercise restraint. At the United Nations, Chinese Foreign Minister Wang Yi counseled enforcement of sanctions along with his usual urging all parties to manage the issue peacefully through dialogue. ${ }^{29}$

Thus, it now appears that the Trump administration is giving China some flexibility in determining which actions it will take with respect to North Korea. There are some indications that China is putting real pressure on North Korea. In April, e.g., there were rumors that Beijing was responsible for recent fuel shortages Pyongyang due to a tightening of sanctions. ${ }^{30}$ However, others have criticized whether China is taking recent sanctions seriously due to a recent report that, despite a recent coal ban, several North Korean coal ships were seen in Chinese ports for 'humanitarian' reasons.

To what extent will China cooperate with the sanctions remains to be seen. However, China's willingness to confront North Korea seems to be a litmus test for the future US-China relations during the Trump administration. Trump 
desperately needs a political win considering the precarious start to his first term. Resolving the North Korea nuclear issue that has plagued US administrations since the 1990s would certainly help his political fortunes. Trump is not a traditional politician. The transactional nature of his character would seem to indicate that cooperation on the North Korea issue would lead to better economic relations between the US and China, e.g., which may be seen already in the toning down of the currency manipulator and trade cheating rhetoric Trump used during the campaign.

Yet, while the Trump administration has toned down some rhetoric against China, certain actions it has taken have put increasing strain on the US-China relations. E.g., President Trump signed a memorandum pursuant to 232(b) of the Trade Expansion Act to press Chinese enterprises for dumping steel into the US market. ${ }^{32}$ When asked if now is the appropriate time to pressure China on the new steel cases and whether the administration was concerned of retaliation in kind or China not cooperating on the North Korea issue, Secretary of Commerce, Wilbur Ross, noted that the administration would do what is necessary to protect the American national security interests. ${ }^{33}$ A tougher approach by the administration may become more likely, especially in light of continuing testing of nuclear and missile technologies by North Korea, which has been seen as a failure of the Chinese government to reign in the Kim regime, and a failure of the Trump administration, which was relying heavily on its Chinese counterpart. ${ }^{34}$ Therefore, it is critical and likely that both countries will work together through the use of targeted secondary sanctions in order to achieve their desired political ends.

\section{REFERENCES}

1. E. Osnos, Can Trump Match Xi Jinping's Game, New Yorker, Apr. 4, 2017, available at http://www.newyorker.com/news/evan-osnos/can-trump-match-xi-jinpings-game (last visited on Aug. 1, 2017).

2. See, e.g., P. Navarro, Trump's 45\% Tariff on Chinese Goods is Perfectly Calculated, L.A. Times, July 21, 2016, available at http:/www.latimes.com/opinion/op-ed/la-oe-navarrotrump-trade-china-tariffs-20160721-snap-story.html (last visited on Aug. 1, 2017).

3. China Has a Steely Reminder for Donald Trump, Fortune, Nov. 24, 2016, available at http:// fortune.com/2016/11/24/donald-trump-china-trade-tariff (last visited on Aug. 1, 2017). 
4. B. Appelbaum, Trump Taps Peter Navarro, Vocal Critic of China, for New Trade Post, N.Y. Times, Dec. 21, 2016, available at https://www.nytimes.com/2016/12/21/us/politics/peternavarro-carl-icahn-trump-china-trade.html (last visited on Aug. 1, 2017).

5. P. Navarro, Death by China: How America Lost Its Manufacturing Base (Official Version), YouTuBE, Apr. 10, 2016, available at https://www.youtube.com/watch? $\mathrm{v}=\mathrm{mMlmjXtnIXI} \mathrm{(last}$ visited on Aug. 1, 2017).

6. See Donald J. Trump's 7 Point Plan to Rebuild the American Economy by Fighting for Free Trade, available at https://www.donaldjtrump.com/policies/trade (last visited on Aug. 1, 2017).

7. S. Collinson, N. Gaouette, E. Labott \& L. Smith-Spark, China Lodges Complaint over Trump-Taiwan Call, CNN, Dec. 4, 2016, available at http://edition.cnn.com/2016/12/02/ politics/donald-trump-taiwan (last visited on Aug. 1, 2017).

8. J. Chin, Beijing Concerned by Trump Questioning 'One China' Policy on Taiwan, Wall St. J., Dec. 12, 2016, available at https://www.wsj.com/articles/beijing-seriously-concerned-bytrumps-one-china-remarks-1481529635 (last visited on Aug. 1, 2017).

9. B. Blanchard \& S. Holland, Trump Changes Tack, Backs 'One China' Policy in Call with Xi, Reuters, Feb. 10, 2017, available at http://www.reuters.com/article/us-usa-trump-chinaidUSKBN15P0ED (last visited on Aug. 1, 2017).

10. K. Hunt, T. Schwarz \& E. Bradner, Beijing 'Seriously Concerned' after Trump Questions 'One China' Policy, CNN, Dec. 13, 2016, available at http://edition.cnn.com/2016/12/12/ politics/china-trump-one-china-reaction (last visited on Aug. 1, 2017).

11. Id.

12. P. Baker, Trump Abandons Trans-Pacific Partnership, Obama's Signature Trade Deal, N.Y. Times, Jan. 23, 2017, available at https:/www.nytimes.com/2017/01/23/us/politics/tpptrump-trade-nafta.html (last visited on Aug. 1, 2017).

13. See Presidential Memorandum Regarding Withdrawal of the United States from the TransPacific Partnership Negotiations and Agreement: Memorandum for the United States Trade Representative, The White House Press Release, Jan. 23, 2017, available at https:// www.whitehouse.gov/the-press-office/2017/01/23/presidential-memorandum-regardingwithdrawal-united-states-trans-pacific (last visited on Aug. 1, 2017).

14. See, e.g., Statement by SASC Chairman John McCain on President Trump's Decision to Withdraw from the Trans-Pacific Partnership, Press Release, Jan. 23, 2017, available at https://www.mccain.senate.gov/public/index.cfm/press-releases?ID=75B5FF88-7343-427CBC95-E2D4960E8B3B (last visited on Aug. 1, 2017). McCain said: "President Trump's decision to formally withdraw from the Trans-Pacific Partnership (TPP) is a serious mistake that will have lasting consequences for America's economy and our strategic position in the Asia-Pacific Region."

15. F. Kleiner, Trump Leaves Asia Door Open for China to Dominate Trade, Fin. Times, Mar. 2, 2017, available at https://www.ft.com/content/2fe572fc-ff39-11e6-96f8-3700c5664d30 (last 
visited on Aug. 1, 2017)

16. R. Daly, What Will US-China Relations Look Like Under Trump?, Wilson Center, Jan. 25, 2017, available at https://www.wilsoncenter.org/article/what-will-us-china-relations-lookunder-trump. See also Z. Juan, H. Nan, P. Wenjie \& S. Tiezzi, The Experts Speak: What Will US-China Relations Look Like under Trump?, Diplomat, Jan. 24, 2017, available at http://thediplomat.com/2017/01/the-experts-speak-what-will-us-china-relations-look-likeunder-trump (all last visited on Aug. 1, 2017).

17. P. Griffin, CFIUS in the Age of Chinese Investment, 85 Fordham L. Rev. 1785 (2017).

18. Id.

19. M. Pennington, 'Maximum Pressure and Engagement': Trump Administration Settles on a North Korean Strategy, Associated Press, Apr. 14, 2017, available at http://news. nationalpost.com/news/world/maximum-pressure-and-engagement-trump-administrationsettles-on-a-north-korean-strategy (last visited on Aug. 1, 2017).

20.See@realDonaldTrump, available at https://twitter.com/realDonaldTrump?lang=en (last visited on Aug. 1, 2017). [Emphasis added]

21. See e.g., China Speaks about President Donald Trump, South China Sea, Trade (Full Interview), NBC News, Jan. 24, 2017, available at https://www.youtube.com/watch?v $=\mathrm{d} 7 \mathrm{~J} 6 \mathrm{wFa}-\mathrm{vYc}$ (last visited on Aug. 1, 2017).

22. Press Briefing by Press Secretary Sean Spicer, 4/17/2017, \#38, The White House Press Release, available at https://www.whitehouse.gov/the-press-office/2017/04/17/pressbriefing-press-secretary-sean-spicer-4172017-38 (last visited on Aug. 1, 2017). [Emphasis added]

23. Y. Torbati, U.S. Readying New North Korea Sanctions If Needed: Tillerson, Reuters, May 3, 2017, available at http://www.reuters.com/article/us-northkorea-usa-tillersonidUSKBN17Z1RL (last visited on Aug. 1, 2017).

24. Report of the Panel of Experts established pursuant to resolution 1874, Note by the President of the Security Council, U.N. Doc. S/2016/157 (Feb. 24, 2016), available at http:// www.un.org/ga/search/view_doc.asp?symbol=s/2016/157. See also, B. Klingner, Chinese Foot-Dragging on North Korea Thwarts U.S. Security Interests, The Heritage Foundation Report, Aug. 11, 2016, available at http://www.heritage.org/defense/report/chinese-footdragging-north-korea-thwarts-us-security-interests (all last visited on Aug. 1, 2017).

25. R. Tillerson, Remarks to U.S. Department of State Employees (May 3, 2017), available at https://www.state.gov/secretary/remarks/2017/05/270620.htm. See also Jae-soon Chang, Tillerson Warns of Additional Sanctions, Secondary Boycotts over N. Korea, YonHAP NEwS, May 4, 2017, available at http://english.yonhapnews.co.kr/northkorea/2017/05/04/0401000 000AEN20170504000400315.html (last visited on Aug. 1, 2017).

26. Torbati, supra note 23.

27. Id.

28. Id. 
29. S. Snyder, Can China Meet President Trump's Expectations on North Korea?, Forbes, May 2, 2017, available at https://www.forbes.com/sites/scottasnyder/2017/05/02/can-chinameet-president-trumps-expectations-on-north-korea/\#102048547181 (last visited on Aug. 1, 2017).

30. E. Talmadge, Gas Restrictions in Force in N. Korean Capital, USA TodAy, Apr. 27, 2017, available at https://www.usatoday.com/story/news/world/2017/04/27/gas-restrictions-forcen-korean-capital/100965990 (last visited on Aug. 1, 2017).

31. B. Blanchard, China Says Enforcing North Korea Coal Ban Seriously, No Violation, REUTERS, Apr. 21, 2017, available at http://www.reuters.com/article/us-china-northkoreacoal-idUSKBN17N12A (last visited on Aug. 1, 2017).

32. See Remarks by President Trump at Signing of the Memorandum Regarding the Investigation Pursuant to Section 232(B) of the Trade Expansion Act, The White House Press Release, Apr. 20, 2017, available at https://www.whitehouse.gov/the-press-office/ 2017/04/20/remarks-president-trump-signing-memorandum-regarding-investigation (last visited on Aug. 1, 2017).

33. See Press Briefing by Secretary of Commerce Wilbur Ross on the Memorandum Regarding the Investigation Pursuant to Section 232 (B) of the Trade Expansion Act, The White House Press Release, Apr. 20, 2017, available at https:/www.whitehouse.gov/the-pressoffice/2017/04/20/press-briefing-secretary-commerce-wilbur-ross-memorandum-regarding (last visited on Aug. 1, 2017).

34. M. Landler \& G. Harris, China Falls Short on Curbing North Korea, Trump Says, N.Y. TIMES, June 20, 2017, available at https:/www.nytimes.com/2017/06/20/world/asia/trumpchina-north-korea.html (last visited on Aug. 1, 2017). 
